\title{
Genetic characterization of morphologically variant strains of Paracoccidioides brasiliensis
}

\author{
Cintia de Moraes Borba/ ${ }^{+}$, Janaina Correia' ${ }^{1}$, Ester Vinhas ${ }^{1}$, Albert Martins ${ }^{1}$, \\ Beatriz Costa Aguiar Alves², Sheila Unkles ${ }^{3}$, James Robertson Kinghorn ${ }^{3}$, Norma Lucena-Silva ${ }^{1}$
}

Departamento de Micologia, Instituto Oswaldo Cruz-Fiocruz, Av. Brasil 4365, 21040-900 Rio de Janeiro, RJ, Brasil ${ }^{1}$ Centro de Pesquisa Aggeu Magalhães-Fiocruz, Recife, PE, Brasil ²Departamento de Imunologia, Instituto de Ciências Biomédicas, Universidade de São Paulo, São Paulo, SP, Brasil ${ }^{3}$ School of Biology, University of St. Andrews, United Kingdom

Molecular characterization of Paracoccidioides brasiliensis variant strains that had been preserved under mineral oil for decades was carried out by random amplified polymorphic DNA analysis (RAPD). On P. brasiliensis variants in the transitional phase and strains with typical morphology, RAPD produced reproducible polymorphic amplification products that differentiated them. A dendrogram based on the generated RAPD patterns placed the 14 P. brasiliensis strains into five groups with similarity coefficients of $72 \%$. A high correlation between the genotypic and phenotypic characteristics of the strains was observed. A $750 \mathrm{bp}$-RAPD fragment found only in the wild-type phenotype strains was cloned and sequenced. Genetic similarity analysis using BLASTx suggested that this RAPD marker represents a putative domain of a hypothetical flavin-binding monooxygenase (FMO)-like protein of Neurospora crassa.

Key words: FMO - Paracoccidioides brasiliensis - RAPD-PCR

Paracoccidioides brasiliensis (Splendore) Almeida, 1930 is an anamorphic and dimorphic fungus $\left(23^{\circ} \mathrm{C}\right.$ filamentous phase; $36^{\circ} \mathrm{C}$ - yeast-like phase) that causes paracoccidioidomycosis, a serious disease in humans that is prevalent in South America and particularly Brazil (Lacaz 1982). It is believed that the phase transition from mold to yeast is essential for activating pathogenicity, and the mechanism that regulates this switch is still unknown (Nemecek et al. 2006). Factors such as successive subculturing and storage in vitro (Brummer et al. 1990) result in changes to morphology and fungal cell wall content, with concomitant attenuation or complete loss of virulence (Hamdan \& Ferrari 1995, Tanaka et al. 2001, Macoris et al. 2006). In a previous study, we showed that only 18 out of 70 P. brasiliensis strains that had been isolated from individual patients and preserved under mineral oil for periods of time up to 45 years were viable (Mendes da Silva et al. 1994). However, these strains (except Pb IOC 3698) remained morphologically in the transitional phase (i.e., thick filaments, yeast-like cells and buds, instead of thin spidery filaments) at $23^{\circ} \mathrm{C}$. They were also found to be nonvirulent, as seen from studies using rat and mice models (Mendes da Silva et al. 1996, Borba \& Schäffer 2002). By detecting the presence of either the GP43 protein or the $g p 43$ gene, we confirmed the identity of the morphologically variant $P$. brasiliensis, that remained in the transitional phase (Borba et al. 2005).

\footnotetext{
Financial support: Fiocruz, British Council Program

+ Corresponding author: cborba@ioc.fiocruz.br

Received 23 October 2007

Accepted 24 April 2008
}

The genetic diversity of $P$. brasiliensis has been assessed by random amplified polymorphic DNA (RAPD) analysis (Molinari-Madlum et al. 1999, Kurokawa et al. 2005), restriction fragment length polymorphism (RFLP) (Niño-Vega et al. 2000) and polymorphic microsatellites located on noncoding and coding sequences (Nascimento et al. 2004, Matute et al. 2006). RAPD technology has also been successfully used to distinguish pathogenic and nonpathogenic strains of other fungi (Aufauvre et al. 1992, Guthrie et al. 1992, Woods et al. 1993, Mondon et al. 1995, Lasker 2002). In the present study, we used RAPD analysis to identify molecular markers related to morphological alterations and/or pathogenic impairment of morphologically variant $P$. brasiliensis strains.

Fourteen $P$. brasiliensis strains were grown on PYG agar (Mendes da Silva et al. 1994). The strains Pb IOC 949, 950, 1059, 1099, 1124, 1148, 1163, 1205, 1208, 1210, 1479 and 3698 were obtained from the Culture Collection of the Instituto Oswaldo Cruz-Fiocruz, Rio de Janeiro, Brazil. Two strains, $\mathrm{Pb} 18$ and 339, were kindly provided by Dr. Rosely Zancopé (Laboratório de Micologia, Hospital Evandro Chagas-Fiocruz, Rio de Janeiro, Brazil). All the strains were incubated at $23^{\circ} \mathrm{C}$ and $36^{\circ} \mathrm{C}$, and after 13 days the strains were examined under an optical microscope (Axiophot model, Zeiss, Germany). The fungal cells were stained using Amann's lactophenol cotton blue. DNA was extracted, quantified and assessed as described by Borba et al. (2005). RAPDpolymerase chain reaction (PCR) was performed using six different primers named OPF-01 (ACGGATCCTG), OPF-08 (GGGATATCGG), OPF-11 (TTGGTACCCC), OPF-12 (ACGGTACCAG), OPF-13 (GGCTGCAGAA) and OPF-14 (TGCTGCAGGT) (Operon Technologies, Inc., USA). The reaction mixture was set up consisting of 1x buffer without $\mathrm{MgCl}_{2}$ (Gibco BRL, USA), $1.5 \mathrm{mM}$ $\mathrm{MgCl}_{2}, 16 \mu \mathrm{M}$ dNTP, 9\% glycerol, 50 pmol of primer, 1 U of Taq polymerase (Gibco) and 30 ng of DNA template, 
in a final volume of $25 \mu$ l. This was then overlaid with $30 \mu \mathrm{l}$ of mineral oil. The amplification program consisted of 30 cycles of $94^{\circ} \mathrm{C}$ for $1 \mathrm{~min}, 36^{\circ} \mathrm{C}$ for $1 \mathrm{~min}$ and $72^{\circ} \mathrm{C}$ for 2 min, using a DNA thermal cycler (Perkin-Elmer Corporation, USA). The resulting amplified fragments were analyzed by electrophoresis in a $2 \%$ agarose gel/TAE buffer. The gels were stained for $15 \mathrm{~min}$ with $0.05 \mu \mathrm{g} / \mathrm{ml}$ ethidium bromide/TAE and photographed under UV light using Polaroid film. The electrophoretic DNA profiles were used to determine the similarity of DNA fingerprint patterns by calculating a simple matching coefficient. An agglomerate method for clustering accessions (unweighted pair group method with arithmetic mean, UPGMA) was used. The DNA profiles produced were analyzed using the NTSYS-pc software, version 1.70. A 750 bp DNA fragment was isolated from the virulent strains, $\mathrm{Pb}$ IOC 3698 and $\mathrm{Pb} 339$, and ligatingthe DNA fragment was ligated into a TA vector (PinPointTM Xa-1 T-Vector, Promega) and then transformed into Escherichia coli DH5- $\alpha$ cells. The identity of the cloned insert was confirmed by PCR using vector-specific primers. The reaction mixture was set up consisting of $1 \mathrm{x}$ buffer without $\mathrm{MgCl}_{2}, 1.5 \mathrm{mM} \mathrm{MgCl}, 2 \mathrm{mM}$ dNTP, $25 \mathrm{pmol}$ of the primers TAF (CGAAGGTCGCGAAGCTTCAGC) and TAR (GATCGCGGCCGCCCCGGGAG), $1 \mathrm{U}$ of Taq polymerase and $5 \mu \mathrm{l}$ of recombinant clone suspensions from $\mathrm{Pb}$ IOC 3698 and $\mathrm{Pb}$ 339. This was then overlaid with $30 \mu \mathrm{l}$ of mineral oil. The amplification program consisted of 30 cycles of $94^{\circ} \mathrm{C}$ for $30 \mathrm{~s}, 60^{\circ} \mathrm{C}$ for $30 \mathrm{~s}$ and $72^{\circ} \mathrm{C}$ for $2 \mathrm{~min}$, performed in a Perkin-Elmer DNA thermal cycler. An amplicon of 850 bp in size was viewed by electrophoresis on $1 \%$ agarose/TAE gel, as described earlier. The amplicon was isolated and purified by using the Concert gel extraction system (Gibco), in accordance with the manufacturer's instructions. The nucleotide sequence of the $850 \mathrm{bp}$ fragment was determined by using the Thermo Sequenase Cy5 dye terminator cycle sequencing kit (Amersham Pharmacia Biotech, USA) in an ALFexpress II sequencer (Amersham). The sequences obtained were analyzed using the BLAST software. The $850 \mathrm{bp}$ fragment was named ceja-1. Specific primers for the ceja-1 sequence were designed using the Oligos 4.0 software. Their specificity was first examined by PCR using gDNA of the morphologically typical pathogenic strains ( $\mathrm{Pb}$ 18, $\mathrm{Pb} 339$ and $\mathrm{Pb}$ IOC 3698) and morphologically variant non-pathogenic strains (Pb IOC 1059, $\mathrm{Pb}$ IOC 1124, Pb IOC 1208 and Pb IOC 1210). The reaction mixture was set up consisting of $1 \mathrm{x}$ buffer, $1.5 \mathrm{mM}$ $\mathrm{MgCl}_{2}, 0.2 \mathrm{mM}$ dNTP, $25 \mathrm{pmol}$ of the primers PBEXF (5'GC'GGGTCCCCAAAAGGATCTGGC) and PBEXR (5'AAAAGATTGCTCTCCTGGACGCGTCG), 1 U of Taq polymerase and $25 \mathrm{ng}$ of gDNA. This was then overlaid with $30 \mu \mathrm{l}$ of mineral oil. The amplification program consisted of 30 cycles of $94^{\circ} \mathrm{C}$ for $30 \mathrm{~s}, 68^{\circ} \mathrm{C}$ for $1 \mathrm{~min}$ and $72^{\circ} \mathrm{C}$ for $1 \mathrm{~min}$. The ceja-1 amplified fragment was $400 \mathrm{bp}$ in length and was analyzed by electrophoresis in a $1.5 \%$ agarose/TAE gel, as described earlier. RNA from $10 \mathrm{mg}$ of dry P. brasiliensis strains was extracted by the Trizol reagent (Invitrogen, São Paulo, Brazil) and was resuspended in $20 \mu \mathrm{l}$ of DEPC water. cDNA was synthe- sized from $5 \mu$ of RNA using random primers with Superscript RT II, as suggested by the supplier (Invitrogen), prior to amplification of the ceja-1 fragment as described above. Amplification of the constitutive glyceraldehyde 3-phosphate dehydrogenase gene was used as a positive PCR quality control. The resulting fragment was subcloned into a set of pGEX expression vectors covering all three possible open reading frames, and this was used to transform the E. coli BL21 strain. The clones were first screened using specific ceja-amplification by PCR, and then a positive clone was grown in Lurian-Bertani medium supplemented with ampicillin overnight at $37^{\circ} \mathrm{C}$. A $10 \%$ inoculum was grown in fresh medium for $3 \mathrm{~h}$, and then production of the fused protein GST-CEJA1 was induced with $0.1 \mathrm{mM}$ of isopropyl-6-D-thiogalactoside. The proteins were separated by SDS-PAGE, transferred onto a nitrocellulose membrane and probed with mouse serum infected with the wild-type $P$. brasiliensis strain.

The morphological differences and preservation lengths among the $P$. brasiliensis strains studied here are presented in Table. The morphological analysis and strain categorization was done prior to the molecular typing analysis, in order to avoid selection bias. The strains $\mathrm{Pb} 18$ and 339 were maintained on agar slants, showed typical morphology and are described as virulent (Kashino et al. 1990, Vaz et al. 1994). Pb IOC 3698 was the only strain with typical morphology that had been kept under mineral oil, which was for a time period of 16 years, and it is virulent (Borba \& Schäffer 2002). $\mathrm{The} \mathrm{Pb}$ IOC variant strains were classified into three morphological groups on the basis of: (I) large quantities of thin and thick filaments with dilatations and rare yeast-like cells; (II) thick filaments with terminal and intercalary dilatations and yeast-like cells; (III) few thick filaments and large quantities of budding yeastlike cells (Fig. 3). The primer OPF-08 was able to amplify all of the isolates, and the isolates $\mathrm{Pb} 18,339$ and $\mathrm{Pb}$ IOC 3698 presented very similar RAPD fingerprinting (Fig. 1) with a fragment of $750 \mathrm{bp}$ that was not present in the morphologically variant non-pathogenic strains. The RAPD-PCR reactions were repeated on at least three different occasions to ensure reproducibility. The 14 P. brasiliensis strains showed significant genetic diversity, but by taking a threshold similarity coefficient of $72 \%$, it was possible to divide them into five groups (Fig. 2). The strains in the RAPD-a group presented morphological pattern III. The RAPD-b group correlated with morphological group II. The strains in morphological group I were clustered in the RAPD-c group, with the exception of the strain Pb IOC 1205. This did not show any correlation with the DNA fingerprinting pattern of the RAPD-c group, and thus formed a separate group, RAPD-d, despite presenting the same phenotypic characteristics as group I. Strains with typical morphology (group RAPD-e) formed a single group with similarities to each other of 85 to $95 \%$. The ceja-1 fragment was amplified from the gDNA and cDNA of a morphologically typical pathogenic strain of P. brasiliensis, thus suggesting that ceja-1 is a partial sequence of an expressed gene. BLAST-n analysis showed no similarity to any other sequence that has been deposited in GenBank. The ORF 
TABLE

Morphology of Paracoccidioides brasiliensis strains preserved under mineral oil for various periods of time at room temperature that were used for RAPD genotyping

\begin{tabular}{lcl}
\hline Pb IOC strains & Preservation (years) & Morphology \\
\hline 949 & 33 & \\
950 & 46 & \\
1099 & $\mathrm{u}$ & Thin and thick filaments with dilatations \\
1148 & 37 & and rare yeastlike cells \\
1163 & 42 & \\
1205 & 46 & \\
1210 & 37 & Thick filaments with terminal and intercalary \\
\hline 1124 & 42 & dilatations. Presence of yeastlike cells \\
1208 & 46 & Thick filaments and large quantities of \\
\hline 1059 & 42 & budding yeastlike cells \\
1479 & 41 & Delicate hyphae with chlamydospores \\
\hline 3698 & 16 & \\
\hline
\end{tabular}

u: unknown.

Finder software identified several potential ORFs ranging from 114 to $237 \mathrm{bp}$. BLAST-x analysis revealed homology with a domain of a hypothetical flavin-binding monooxygenase-like protein of Neurospora crassa. The results from the polypeptide sequence alignment using BLAST-p showed low homology with a value of $\mathrm{e}^{-10}$. The GST-CEJA1 recombinant protein was recognized by mouse serum infected with a morphologically typical virulent strain of $P$. brasiliensis.

In the present study, we showed that dimorphism impairment and virulent behavior were associated with genetic polymorphisms of $P$. brasiliensis strains. The phenomenon of in vitro attenuation of virulence has been described for $P$. brasiliensis (Kurokawa et al. 2005), and the strain virulence can be recovered after several passages through animals (Carvalho et al. 2005). However, the morphologically variant strains Pb IOC 1210, 1208, 1124 and 1059 used here continued to be nonvirulent after inoculation in rats and mice by the intraperitoneal route (Mendes da Silva et al. 1996, Borba \& Schäffer 2002), thus suggesting the existence of stable non-virulence even after passage through animals. We showed that the OPF-08

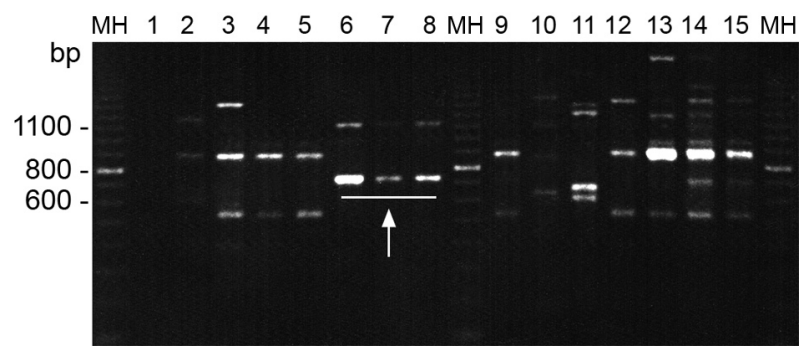

Fig. 1: comparison of RAPD-PCR genetic patterns with DNA prepared from 14 strains of $P$. brasiliensis using the $\mathrm{OPF}-08$ primer and $1.5 \mathrm{mM}$ $\mathrm{MgCl}_{2}$. The amplification reactions are described in the text. Lanes - 1: negative control; 2: Pb IOC 1059; 3: Pb IOC 1208; 4: $\mathrm{Pb}$ IOC 1210; 5: Pb IOC 1099; 6: Pb 339; 7: Pb 18; 8: Pb IOC 3698; 9: Pb IOC 1163; 10: Pb IOC 1205; 11: Pb IOC 1479; 12: Pb IOC 1124; 13: Pb IOC 950; 14: Pb IOC 949; and 15: Pb IOC 1148. Molecular weight (MH) markers: 100 bp DNA ladder is shown. The arrow indicates the $750 \mathrm{bp}$ fragment that was present in the virulent strains.

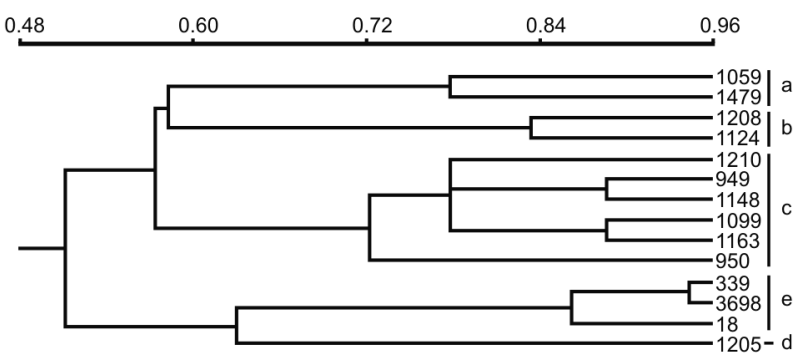

Fig. 2: dendrogram of $P$. brasiliensis strains based on genetic similarity coefficients derived from RAPD-PCR using the OPF-08 primer, showing five groups with similarity of at least $72 \%$.

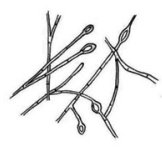

mycelial phase
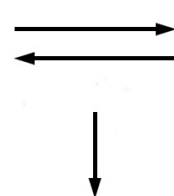

transitional phases

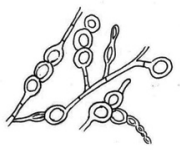

II

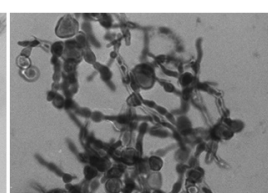

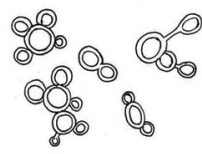

yeast-like phase

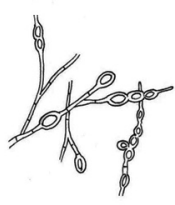

।

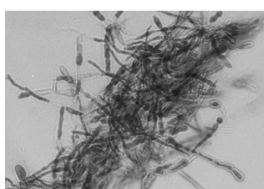

Fig. 3: diagram and microphotographs (original magnification, 400X) of the morphologies observed for $P$. brasiliensis strains based on Salazar \& Restrepo (1984). Strains were grown on PYG agar. I: large quantities of thin and thick filaments with dilatations and rare yeastlike cells; II: thick filaments with terminal and intercalary dilatations and yeast-like cells; III: few thick filaments and large quantities of budding yeast-like cells. 
primer provided a RAPD pattern that was reproducible and discriminated between virulent strains with typical morphology and nonvirulent strains with atypical morphology. The technique of RAPD analysis used in association with virulence, morphological and immunological characteristics might prove adequate for detecting differences between $P$. brasiliensis isolates (Kurokawa et al. 2005). Additionally, we identified one expressed sequence (ceja-1) that was selectively present in morphologically typical virulent strains. The function of the ceja-1 sequence remains to be determined. In conclusion, RAPD methodology proved to be simple, inexpensive and appropriate for genetic discrimination of virulent and nonvirulent strains.

Nucleotide sequence accession number - The nucleotide sequence of the ceja-1 fragment from $P$. brasiliensis was submitted to GenBank. Accession number: AY665294 ( $\mathrm{Pb}$ IOC 3698).

\section{ACKNOWLEDGEMENTS}

To Dr. Marcos Moraes from the Universidade Federal de Pernambuco, who provided the primers, and Alex Sandro D Albuquerque from Instituto Oswaldo Cruz who performed the lyophilization of the strains.

\section{REFERENCES}

Aufauvre-Brown A, Coheen J, Holden DW 1992. Use of randomly amplified polymorphic DNA markers to distinguish isolates of Aspergillus fumigatus. J Clin Microbiol 30: 2991-2993.

Borba CM, Schäffer GV 2002. Paracoccidioides brasiliensis: Virulence and attempt to induce the dimorphic process with fetal calf serum. Mycoses 45: 174-179.

Borba CM, Vinhas EAL, Lopes-Bezerra LM, Lucena-Silva N 2005. Morphological, biochemical and molecular approaches for comparing typical and atypical Paracoccidioides brasiliensis. Antonie van Leeuwenhoek 88: 257-266.

Brummer E, Restrepo A, Hanson LH, Stevens DA 1990. Virulence of Paracoccidioides brasiliensis: The influence of in vitro passage and storage. Mycopathologia 109: 13-17.

Carvalho KC, Ganiko L, Batista WL, Morais FV, Marques ER, Goldman GH, Franco MF, Puccia R 2005. Virulence of Paracoccidioides brasiliensis and gp43 expression in isolates bearing known PbGP43 genotype. Microbes Infect 7: 55-65.

Guthrie PAJ, Magill CW, Frederiksen RA, Odvody GN 1992. Random amplified polymorphic DNA markers: a system form identifying and differentiating isolates of Colletotrichum graminicola. Phytopathology 82: 832-835.

Hamdan JS, Ferrari TCA 1995. An atypical isolate of Paracoccidioides brasiliensis. Mycoses 38: 481-484.

Kashino SS, Singer-Vermes LM, Calich VLG, Burger E 1990. Alterations in the pathogenicity of one Paracoccidioides brasiliensis isolate do not correlative with its in vitro growth. Mycopathologia 111: 173-180.

Kurokawa CS, Lopes CR, Sugizaki MF, Kuramae EE, Franco MF, Peraçoli MT 2005. Virulence profile of ten Paracoccidioides brasiliensis isolates: association with morphologic and genetic patterns. Rev Inst Med Trop São Paulo 47: 257-262.
Lacaz CS 1982. Evolução dos conhecimentos sobre a paracoccidioidomicose. Um pouco da história. In G del Negro, CS Lacaz, AM Fiorillo (eds), Paracoccidioidomicose Blastomicose SulAmericana, Sarvier, São Paulo, p. 1-9.

Lasker BA 2002. Evaluation of performance of four genotypic methods for studying the genetic epidemiology of Aspergillus fumigatus isolates. J Clin Microbiol 40: 2886-2892.

Macoris SAG, Sugizaki MF, Peraçoli MTS, Bosco SMG, HebelerBarbosa F, Simões LB, Theodoro RC, Trinca LA, Bagagli E 2006. Virulence attenuation and phenotypic variation of Paracoccidioides brasiliensis isolates obtained from armadillos and patients. Mem Inst Oswaldo Cruz 101: 331-334.

Matute DR, Sepulveda VE, Quesada LM, Goldman GH, Taylor JW, Restrepo A, McEwen JG 2006. Microsatellite analysis of three phylogenetic species of Paracoccidiodes brasiliensis. J Clin Microbiol 44: 2153-2157.

Mendes da Silva AM, Borba CM, Oliveira PC 1994. Viability and morphological alterations of Paracoccidioides brasiliensis strains preserved under mineral oil for long periods of time. Mycoses 37: 165-169.

Mendes da Silva AM, Borba CM, Oliveira PC 1996. Inoculation experimental animals with Paracoccidioides brasiliensis strains: An attempt to re-establish the dimorphic process and variation in pathogenicity as a function of time of preservation under mineral oil. Mycopathologia 133: 135-138.

Molinari-Madlum EWI, Felipe MSS, Soares CMA 1999. Virulence of Paracoccidioides brasiliensis isolates can be correlated to groups defined by random amplified polymorphic DNA analysis. Med Mycol 37: 269-276.

Mondon P, Thélu J, Lebeau B, Ambroise-Thomas P, Grillot R 1995. Virulence of Aspergillus fumigatus strains investigated by random amplified polymorphic DNA analysis. J Med Microbiol 42: 299-303.

Nascimento E, Martinez R, Lopes AR, Bernardes LAS, Barco CP, Goldman MHS, Taylor J, McEwen JG, Nobrega MP, Nobrega FG, Goldman GH 2004. Detection and selection of microsatellites in the genome of Paracoccidioides brasiliensis as molecular markers for clinical and epidemiological studies. J Clin Microbiol 42: 5007-5014.

Nemecek JC, Wüthrich M, Klein BS 2006. Global control of dimorphism and virulence in fungi. Science 312: 583-588.

Niño-Vega GA, Calcagno AM, San-Blas G, San-Blas F, Gooday GW, Gow NA 2000. RFLP analysis reveals marked geographical isolation between strains of Paracoccidioides brasiliensis. Med Mycol 38: 437-441.

Salazar ME, Restrepo A 1984. Morphogenesis of the mycelium to yeast transformation in Paracoccidioides brasiliensis. Sabouraudia. J Med Vet Mycol 22: 7-11.

Tanaka R, Sano A, Franco M, Bagagli E, Rubens Montenegro M, Nishimura K, Miyaji M 2001. Cerebriform colonies of Paracoccidioides brasiliensis isolated from nine-banded armadillos (Dasypus novemcinctus) at room temperature. Mycoses 44: 9-12.

Vaz CAC, Mackenzie WR, Hearn V, Camargo ZP, Singer-Vermes LM, Burger E, Calich VLG 1994. Gelatinase activity of exoantigens from virulent and non-virulent isolates of Paracoccidioides brasiliensis. J Med Vet Mycol 32: 65-69.

Woods JP, Kersulyte D, Goldman WE, Berg DE 1993. Fast DNA isolation from Histoplasma capsulatum: methodology for arbitrary primer polymerase chain reaction-based epidemiological and clinical studies. J Clin Microbiol 31: 463-464. 